\title{
Freedom, Equality and Justice in Islam
}

\section{Mohammad Hashim Kamali}

Cambridge, UK: Islamic Texts Society, 2002. 184 pages.

Modern Muslim thinkers who try to locate and construct constitutional tenets based on the Islamic tradition face various difficulties, for they have 
to address a segment of an audience that expects an exposition comparable to the West's in terms of terminologies, institutions, and remedies, as well as to draw from the best practices of Islamic history and modern Muslim societies. It is always frustrating to learn that Islam's constitutional history, despite its richness in individual constitutional tenets, loses some of its utility in modern Muslim societies due to systemic changes caused by globalization and pervasive international institutions, both of which have had far-reaching consequences on domestic sociopolitical settings.

Given the contemporary nation-state's overarching authority, one known guarantee of the people's social, legal, or political rights is a constitutional framework under a credible rule of law system. Mohammad Hashim Kamali's Freedom, Equality and Justice in Islam identifies the three themes in the title of his book as the fundamental bases upon which all other constitutional guarantees of human rights depend.

The book is divided into three chapters, each dedicated to one of the main themes. The first chapter, which discusses freedom, presents a conceptual analysis of the term and how it is expressed in Islam's theological and sociopolitical contexts. However, unlike various guarantees provided for realizing other values, such as justice (discussed in chapter 3), there is little discussion of such practical guarantees for personal liberty and freedom. The author acknowledges that Muslims have given scant attention to constitutional guarantees of freedom, citing the prevalence of despotic governments throughout much of Islamic history. Nevertheless, the only way he offers out of this situation is to observe that Muslims should change the language of fiqh (Islamic jurisprudence) to reflect the challenging times confronting the ummah. This may not be surprising, given the identified problems, as mentioned above, that have to be faced squarely.

The second chapter, which analyzes equality, reviews authoritative Islamic sources and argues that although there is conclusive evidence that Islam envisages equality in basic rights and duties among all Muslims, the evidence is somewhat inconclusive on whether all members of the human race enjoy such equality. This inconclusiveness is due to sources that leave room for different interpretations and to prevailing circumstances during the formative period of Islamic law. Kamali pays particular attention to the duties and rights of women and non-Muslims, for there are different opinions on women's political and family-law rights and on equal opportunity for non-Muslims. He states that even if differential treatments of the two categories are maintained in certain circumstances, such differences do not negate equality, because Islam's positive equality 
takes natural and acquired distinctions into account. However, the prevalent tendency in modern Islamic reformist thought is unmistakably shifting toward eliminating distinctions based on equivocal evidence when dealing with women and non-Muslims.

The third chapter, which deals with justice, appears to be most incisive, coherent, and deeply rooted in Islam, for justice is an overriding Islamic value regardless of time. Not even nationalist sentiment, which is often used to undermine it (e.g., "my county, right or wrong"), can be Islamic. In this chapter, Kamali reviews in great detail the provisions from the Qur'an and the Sunnah and also indicates how Islamic justice is manifested in the legal and sociopolitical fields. Justice is one of Islam's objectives, and although the path toward it is mainly shown and regulated by the revealed law (the Shari'ah), the quest should not be limited to realizing justice under the rule of law; rather, it should be pursued on all levels.

Regarding the guarantee for realizing the Qur' anic vision of justice in a modern Muslim state, the author remarkably observes that notwithstanding such institutions as hisbah (public or non-governmental enforcement of the common good) and mazalim (bureau for complaint against public officers), among others, justice is best guaranteed by an independent judiciary.

This book is geared toward a constitutional reform system of basic human rights in Muslim countries. In order to make Islamic law more pragmatic and a tangible reality, the author argues that a reform of Islam's constitutional tenets should be carried out in light of each country's institutional framework. The reform method, he argues, need not be wholly Islamic, since Islam shows the way to justice. Therefore, if justice can be attained through other ways that do not violate other Islamic principles, those ways should be adopted. For instance, he cites Islam's distaste for taqlid (juristic imitation) and for the role of binding judicial precedent (i.e., an Anglo-American common-law principle of determinative justice) in many Muslim countries.

Although Islamic jurisprudence has not embraced the idea of a binding judicial precedent, partly due to its concern for protecting the free exercise of ijtihad (deductive reasoning), Kamali extols the advantages of a system based on a binding decision to keep in focus practical legal issues and how their development into practical guidelines impact people's lives. In line with his envisaged reform strategy, Muslim countries should adopt a positive attitude toward a binding judicial precedent at some level, for it can stimulate legal reconstruction and ijtihad. 
The book, which includes a glossary of Islamic terms and an index, is a rich source of information on textual provisions and a historical account of how human rights were protected during the early period of Islamic civilization. It is a helpful starting point for those seeking evidence, rather than a deep analysis, on the concepts and manifestations of freedom, equality, and justice in Islam.

Ali Ahmad

Faculty of Law

Bayero University, Kano, Nigeria 